\title{
Substantial record of whitecheek monocle bream, Scolopsis vosmeri (Family: Nemipteridae), from Iraqi marine waters
}

\author{
Laith A. Jawad, Falah M. Mutlak, Abbas J. AL-Faisal and Baradi Waryani
}

Received - 10 May 2020/Accepted - 01 February 2021. Published online: 31 March 2021; @Inland Fisheries Institute in Olsztyn, Poland Citation: Jawad, L.A., Mutlak, F.M., AL-Faisal, A.J., and Baradi Waryani (2021). Substantial record of whitecheek monocle bream, Scolopsis vosmeri (Family: Nemipteridae), from Iraqi marine waters. Fisheries \& Aquatic Life 29(1), 45-49

\begin{abstract}
Three specimens of whitecheek monocle bream, Scolopsis vosmeri (Bloch) were collected from Iraqi marine waters in the northwest Arabian Gulf. This is a substantial, confirmed record of this species from Iraqi marine waters. Body coloration characterizes this species. The presence of this species was revealed as a result of comprehensive ichthyological investigative work in the area.
\end{abstract}

Keywords: Basra, Iraq, Arabian Gulf, range extension, new record

\section{Introduction}

Iraqi territorial marine waters are situated in the northwest part of the Arabian Gulf, which is a shallow, marginal northern expansion of the Indian Ocean (Pous et al. 2012). This part of the world is characterized by its receipt of enormous quantities of

\footnotetext{
L.A. Jawad [ڤ"]

School of Environmental and Animal Sciences, Unitec Institute of Technology, 139 Carrington Road, Mt Albert,

Auckland 1025, New Zealand

E-mail: laith_jawad@hotmail.com

F.M. Mutlak, A.J. AL-Faisal

Marine Science Centre, University of Basra, Basra, Iraq

Baradi Waryani

Department of Fresh Water Biology and Fisheries, University of

Sindh, Jamshoro, Sindh, Pakistan
}

fluvial input from the Shatt Al-Arab River, the confluent delta of the Tigris and Euphrates rivers. The salinity level in this area fluctuates during the different months of the year. Among the important changes that occur in the northern part of the Arabian Gulf is the high plankton productivity resulting from high nutrient levels brought by freshwater influxes of the Shatt al-Arab River (Al-Kandari et al. 2009, Al-Yamani and Saburova 2010, 2011). Such environments usually act as suitable feeding grounds for several fish species and attract many others from different regions of the Gulf.

The whitecheek monocle bream, Scolopsis vosmeri (Bloch) is a marine species inhabiting reef areas at a depth range of 2-25 $\mathrm{m}$ (Lieske and Myers 2002). Individuals of this species are distributed in the Indo-West Pacific region from the Red Sea in the north down the coast of East Africa in the south and toward the east reaching the Ryukyu Islands and northern Australia, and its distribution also includes the Arabian Gulf (Randall 1995). S. vosmeri prefers benthic environments of turbid or weedy waters close to reefs (Sommer et al. 1996) and although it is mainly solitary, it has been reported to form schools (Kuiter and Tonozuka 2001). This species feeds on benthic organisms (Fischer et al. 1990) and is highly commercially valuable in the areas of its geographical distribution as it is marketed fresh, salted, and 
Table 1

Morphometric and meristic characteristics of Scolopsis vosmeri

\begin{tabular}{|c|c|c|c|}
\hline & Range $(n=3)$ & Mean & SD \\
\hline \multicolumn{4}{|l|}{ Morphometric characters } \\
\hline Total length (mm) & $160-173$ & 164.67 & 5.91 \\
\hline Fork length (mm) & $142-157$ & 147.33 & 6.85 \\
\hline Standard length (SL) (mm) & $124-137$ & 128.67 & 5.91 \\
\hline Body depth \% in SL & $48.49-51.03$ & 49.74 & 1.04 \\
\hline Body width \% in SL & $18.86-20.35$ & 19.44 & 0.65 \\
\hline Head length \% in SL & $33.25-36.43$ & 34.89 & 1.30 \\
\hline Head depth \% in SL & $34.88-36.17$ & 35.41 & 0.55 \\
\hline Head width \% in SL & $18.25-19.75$ & 19.15 & 0.65 \\
\hline Snout length \% in SL & $9.42-10.45$ & 9.92 & 0.42 \\
\hline Eye diameter \% in SL & $10.11-13.68$ & 12.06 & 1.47 \\
\hline Interorbital distance \% in SL & $9.12-10.37$ & 9.85 & 0.53 \\
\hline Predorsal length \% in SL & $31.45-33.62$ & 32.39 & 0.91 \\
\hline Postdorsal length \% in SL & $15.87-17.55$ & 16.51 & 0.74 \\
\hline fin length \% in SL Dorsal & $59.85-62.25$ & 60.68 & 1.11 \\
\hline fin height \% in SL Dorsal & $13.27-14.78$ & 13.85 & 0.67 \\
\hline Anal fin length \% in SL & $19.03-20.14$ & 19.45 & 0.49 \\
\hline Anal fin height \% in SL & $16.91-18.18$ & 17.69 & 0.56 \\
\hline Pectoral fin length \% in SL & $30.75-32.50$ & 31.49 & 0.74 \\
\hline Pelvic fin length \% in SL & $27.55-28.53$ & 28.05 & 0.40 \\
\hline Caudal peduncle length \% in SL & $17.70-21.13$ & 19.31 & 1.41 \\
\hline Caudal peduncle depth \% in SL & $12.11-13.10$ & 12.50 & 0.43 \\
\hline \multicolumn{4}{|l|}{ Meristic characters } \\
\hline Dorsal fin spines & 10 & & \\
\hline Dorsal fin rays & 9 & & \\
\hline Anal fin spines & 3 & & \\
\hline Anal fin rays & 6 & & \\
\hline Pectoral fin rays & 18 & & \\
\hline Pelvic fin rays & 5 & & \\
\hline \multirow{2}{*}{$\begin{array}{l}\text { upper raw } \\
\text { lower raw }\end{array}$} & $4-5$ & & \\
\hline & 5 & & \\
\hline
\end{tabular}

smoked, or it is processed into fish balls (van der Elst 1993). The maximum total length reported for this species is $250 \mathrm{~mm}$ (Russell 1986).

To date, Iraqi marine ichthyofauna has not been fully investigated, and extensive ichthyological research is in progress to identify the fish species composition of this part of the Gulf (Ali 2013, Hussain and Jawad 2014, Jawad and Hussain 2014, Jawad et al. 2014, Jawad and Al-Badri 2015, Al-Faisal et al. 2018, Ali and Iwatsuki 2018).

This paper reports on our study of the presence of the whitecheek monocle bream, S. vosmeri, in the Iraqi marine waters of the Arabian Gulf. Records of this species, which is important to the fisheries of this part of the world, further enrich knowledge of ichthyofauna diversity in this area. The paper also highlights the need for consistently monitoring the ichthyofauna of Iraqi marine areas.

\section{Materials and Methods}

Three specimens of $S$. vosmeri (Fig. 1) were recorded from coastal marine waters of Iraq in the northwestern corner of the Arabian Gulf (29 $47^{\prime}$ N $48^{\circ} 43^{\prime}$ E) in March 2018. The fish specimens were caught from aboard a small trawler operating in an Iraqi commercial fishing marine area and were made available for 


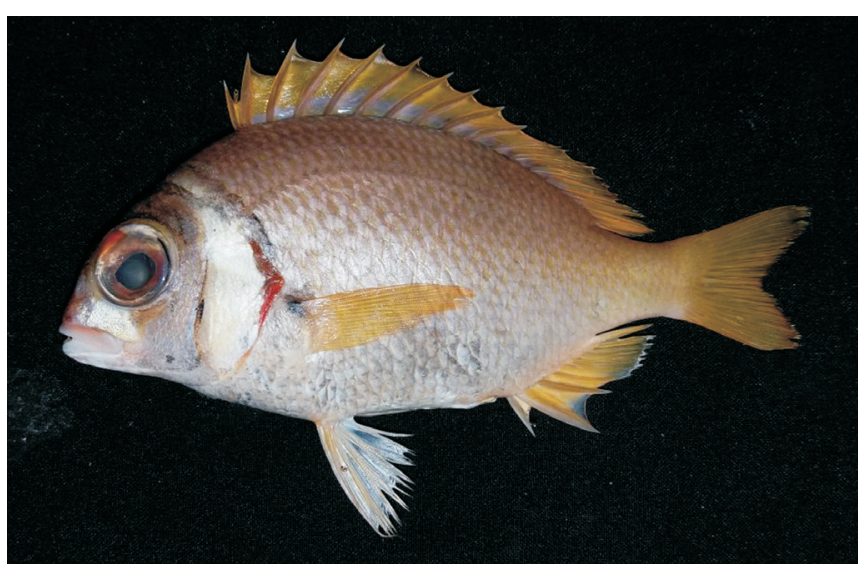

Figure 1. Scolopsis vosmeri, $173 \mathrm{~mm}$ TL, collected from Iraqi marine waters.

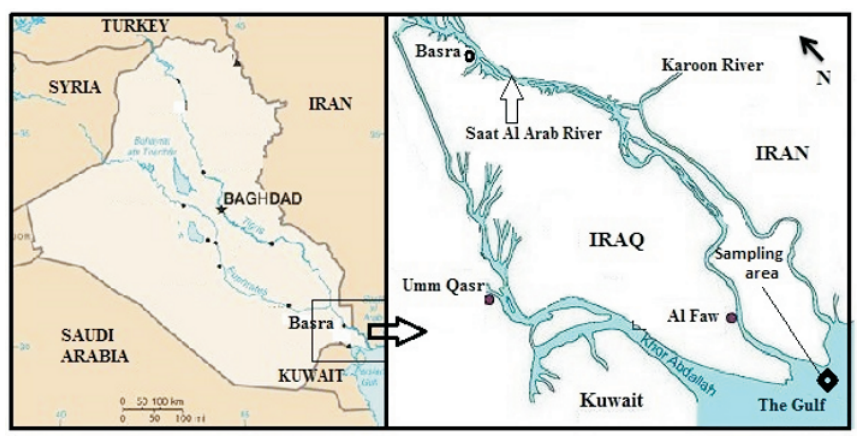

Figure 2. Map of collection locations in the northwest region of the Arabian Gulf.

taxonomic examination (Fig. 2). The meristic and morphometric characters of the specimens were counted and measured according to Russell and Gloerfelt-Tarp (1984). For recording morphometric traits, specimen length was expressed in $\mathrm{mm}$ to the nearest 0.1 . The morphometric and meristic data are presented in Table 1 . The specimens were fixed in $10 \%$ formalin and later preserved in $70 \%$ ethanol, and deposited in the fish collection of the Marine Science Centre, University of Basra, Basra, Iraq.

\section{Results and Discussion}

The three specimens of $S$. vosmeri examined had the following set of characters that corresponded to the description in Russell (1993): deep body with a convex profile and laterally compact; relatively deep; thick jaws; large eyes, with a strong spine located below them; the top of the head had scales that started from the anterior nostrils; the cheeks had four to six transverse rows of scales. The body was a shiny brown on the dorsal side and became whitish toward the ventral side. The head was a pale brown color with white patches on the snout and operculum, which had a red posterior edge; the dorsal, pectoral, anal, and caudal fins were yellow, and the pelvic fins were white.

S. vosmeri was originally described as Anthias vosmeri by Bloch (1792) based on a specimen that measured $120 \mathrm{~mm}$ SL. The range of the standard length of the specimens examined in this study (124-137 mm) was higher than that of the holotype of this species. They were also larger than specimens examined by Kuronuma and Abe (1986) (117 mm SL) from Kuwait, Arabian Gulf; Shen (1997) from Makung, Pescadores Island $(120 \mathrm{~mm}$ SL), Hokato (108 mm SL), and North Borneo (98 mm SL); and Mohapatra et al. (2013) from Digh Mohanna, India (112 mm SL). They were smaller than the specimen studied by Mishra et al. (2013) from Sri Lanka (159 mm SL) and Randall (1995) (160 mm TL). The range of the total length of the three specimens examined was near the upper limit for the maximum total length given by Russell (1986).

Except for Russell (1990), who included a map with the description of $S$. vosmeri that indicated the distribution of the species was expected to be in the Western Indian Ocean, no other reports in the literature refer to the occurrence of this species in Iraqi waters. Therefore, the present report of three specimens of $S$. vosmeri from Iraqi marine waters is a substantial, confirmed record of the occurrence of this species in the area studied.

Scolopsis vosmeri differs from its congener $S$. igcarensis in having a more stout suborbital spine, a less prominent bony ridge below the eye covered with skin, and pectoral fins that do not reach the anus (Mishra et al. 2013). Body coloration also characterizes $S$. vosmeri as it has a white cheek band and sometimes a whitish horizontal stripe below the lateral line from the edge of the opercle to below the soft part of the dorsal fin (Day 1875 and Russell 1990 as 
cited in Mishra et al. 2013). In specimens examined by Randall (1995) and Mishra et al. (2013), the stripe on the head was more yellowish-white, while in the present specimens the stripe was white. The opercular band was missing in S. igcarensis, and together with the characters above, clearly distinguishes it from S. vosmeri.

The coloration of the specimens examined in the present study was similar to that in Kuronuma and Abe (1986) collected from Kuwait, Arabian Gulf, but these specimens differed from that in Randall (1995) in having a whitish ventral side body, which was golden brown in Randall's specimen. Our specimens differed from that of Mishra et al. (2013) in having a dark red posterior edge of the operculum in comparison to the faded red color in their specimen. In contrast, the posterior edge of the preoperculum and the lower edge of the upper jaw were a faded red color in our specimen, while it was dark red in the specimen described in Mishra et al. (2013). Except for the pelvic fins, all the other fins were yellowish in our specimens, while they were bluish-white with faded brown spines and rays in the specimens described in Mishra et al. (2013). Finally, the lateral line was faded brown in our specimens, while it is dark brown in the specimen in Mishra et al. (2013). On the other hand, the specimen examined by Mohapatra et al. (2013) from India was completely golden brown with faded white bands on the snout and operculum with a pale brown lateral line. These differences in coloration are evidence that could indicate that color variation in $S$. vosmeri is a geographical variation.

Since $S$. vosmeri has been recorded in the Arabian Gulf specifically to the north of Kuwait (Kuronuma and Abe 1986), it is possible that the discovery of the three specimens of this species from Iraqi marine waters was the result of the extensive ichthyological work undertaken in this area that could also lead to the discovery of more fish species in the near future.

Author contributions. L.A.J.: ideology, methodology, writing and followed the publication of the paper; F.M.M.: specimen's collection, measurements, description;
A.J.A.F.: specimen's collection, measurements, description, specimen's imaging; B.W.: description, methodology.

Disclosure statement. No potential conflict of interests are reported by the authors.

Funding. No funding was obtained to conduct the present study.

\section{ORCID iD}

Laith A. Jawad (ID https://orcid.org/0000-0002-8294-2944

\section{References}

Al-Faisal, A.J., Mutlak, F.M. (2018). Survey of the marine fishes in Iraq. Bulletin of the Iraq Natural History Museum, 15(2), 163-177.

Ali, A.H. (2013). First record of Strongspine silver-biddy Gerres longirostris (Lacepėde, 1801) (Pisces: Gerreidae) from Iraqi marine territorial waters. Basrah Journal of Agricultural Sciences, 26(1), 178-183.

Ali, A.H., Iwatsuki, Y. (2018). Record of the yellowback grunt Pomadasys aheneus McKay \& Randall (Osteichthyes: Haemulidae) from the Arabian Gulf off Iraq. Zoology in the Middle East, 64(4), 371-373.

Al-Kandari, M., Al-Yamani, F., Al-Rifaie, K. (2009). Marine phytoplankton atlas of Kuwait's waters. Kuwait Institute for Scientific Research, 351.

Al-Yamani, F., Saburova, M.A. (2010). Illustrated Guide on the Flagellate. Kuwait: Kuwait Institute for Scientific Research, 197.

Al-Yamani, F.Y., Saburova, M.A. (2011). Illustrated guide on the benthic diatoms of Kuwait's marine environment. Kuwait Institute for Scientific Research, Kuwait.

Day, F. (1875). The Fishes of India, Being a Natural History of the Fishes Known to Inhabit the Seas and Freshwater of India, Burma and Ceylon. William Dawson \& Sons, London. Part 1.

Fischer, W., Sousa, I.M., Silva, C., De Freitas, A., Poutiers, J.M. (1990). Guia de campo das espécies comerciais marinhas e de águas salobras de Moçambique. Food and Agricultural Organization of the United Nations, Rome.

Hussain, S., Jawad, L.A. (2014). First records of Opisthognathus muscatensis Boulenger, 1888 (Opisthognathidae), Trachinotus baillonii (Lacepede, 1801), and Atrobucca nibe (Jordan \& Thompson, 1911) (Sciaenidae) off the Iraq coast, Arabian Gulf. International Journal of Marine Science, 4(28), 253-258.

Jawad, L.A., Al-Badri, M.E. (2015). Bodianus macrognathos (Teleostei: Labridae), Coris nigrotaenia (Teleostei: Labridae) and Bothus pantherinus (Teleostei: Bothidae) 
in the Iraqi marine waters. North-Western Journal of Zoology, 11(2), 347-350.

Jawad, L.A., Hussain, S. (2014). First record of Antennarius indicus (Pisces: Batrachoidiformes: Antennaridae), Equulites elongatus (Pisces: Perciformes: Leiognathidae) and second record of Cheilinus lunulatus (Pisces: Perciformes: Labridae) from the marine waters of Iraq. International Journal of Marine Science, 4(40), 1-5.

Jawad, L.A., Al-Mukkhtar, M., Faddagh, M.S. (2014). Confirmation of the presence of Heniochus acuminatus (Linnaeus, 1758) (Chaetodontidae) and Pomacanthus maculosus (Forsskll, 1775)(Pomacanthidae) in Iraqi marine waters, Arabian Gulf. Arxius de Miscel·línia Zoolňgica, 12, 124-129.

Kuiter, R.H., Tonozuka, T. (2001). Pictorial guide to Indonesian reef fishes. Part 1. Eels - Snappers, Muraenidae Lutjanidae. Zoonetics, Australia.

Kuronuma, K., Abe, Y. (1986). Fishes of the Arabian Gulf. Kuwait Institute of Scientific Research: Safat, Kuwait.

Lieske, E., Myers, R. (2002). Coral reef fishes: Indo-pacific and Caribbean. Harper Collins Publishers, Milan,

Mishra, S.S., Biswas, S., Russell, B.C., Satpathy, K.K., Selvanayagam, M. (2013). A new species of the genus Scolopsis Cuvier, 1830 (Perciformes: Nemipteridae) from southern India and Sri Lanka. Zootaxa, 3609(4), 443-449.

Mohapatra, A., Tudu, P.C., Ray, D., Yennawar, P. (2013). First report on the occurrence of four fishes of family: Nemipteridae from Digha on the east coast of India. Records of the Zoological Survey of India, 113(1), 145-149.
Pous, S., Carton, X., Lazure, P. (2012). A process study of the tidal circulation in the Persian Gulf. Open Journal of Marine Science, 2(04), 131-140.

Randall, J.E. (1995). Coastal fishes of Oman. Bathurst. New South Wales, Australia: Crawford House Publishing Pty Ltd, 439.

Russell, B.C. (1986) Nemipteridae. In: Smiths' Sea Fishes (Ed.) M.M. Smith, Heemstra P.C., Springer-Verlag, Berlin: 600-601.

Russell, B.C. (1990) Nemipterid Fishes of the World. (Threadfin Breams, Whiptail Breams, Monocle Breams, Dwarf Monocle Breams, and Coral Breams). Family Nemipteridae. An Annotated and Illustrated Catalogue of Nemipterid Species Known to Date. Rome, FAO Fisheries Synopsis no. 125, Volume 12, 149 pp, VIII plates.

Russell, B.C. (1993). A review of the threadfin breams of the genus Nemipterus (Nemipteridae) from Japan and Taiwan, with description of a new species. Japanese Journal of Ichthyology, 39(4), 295-310.

Russell, B.C., Gloerfelt-Trap, T. (1984). A new species of Parascolopsis (Pisces: Nemipteridae) from Indonesia. Beagle, Occasional Papers of the Northern Territory Museum of Arts and Sciences, 1, 111-114.

Shen, S.C. (1997). A review of the genus Scolopsis of nemipterid fishes, with descriptions of three new records from Taiwan. Zoological Studies, 36(4), 345-352.

Sommer, C., Schneider, W., Poutiers, J.M. (1996). FAO species identification guide for fishery purposes. The living mar- ine resources of Somalia. FAO, Rome,

van der Elst, R., (1993). A guide to the common sea fishes of southern Africa. 3rd ed. Cape Town: Struik Publishers. 